\title{
Digitalisasi Pembelajaran Seni Budaya di Kelas XII SMA Negeri 9 Binsus Manado
}

\author{
${ }^{1}$ Fian Panekenan, ${ }^{2}$ Alrik Lapian, ${ }^{3}$ Meyltsan Hebert Maragani \\ Institut Agama Kristen Negeri (IAKN) Manado \\ ${ }^{1}$ fianpanekenan@gmail.com, ${ }^{2}$ alriklapian@yahoo.com, ${ }^{3}$ ilzan_maragani@iakn-manado.ac.id
}

\begin{abstract}
Abstrak
Penelitian ini bertujuan untuk menjelaskan proses digitalisasi pembelajaran di SMA $\mathrm{N} 9$ Manado mulai dari persiapan materi digital, penerapan aplikasi microsoft 365, serta proses penerapan pembelajaran seni budaya secara digital. Penelitian ini merupakan penelitian kualitattif menggunakan studi kasus. Data dikumpulkan melalui observasi, wawancara dan hasil dokumentasi. Penelitian ini dilakukan dengan menggunakan metode kualitatif dan memanfaatkan data deskriptif yang berkaitan dengan pengumpulan data untuk memberikan gambaran atau penegasan suatu konsep atau fenomena terkait digitalisasi pembelajaran seni budaya di SMA N 9 Binsus Manado.Dari hasil analisis dan interpretasi data diperoleh indikasi bahwa : (1) proses kegiatan belajar mengajar dilakukan secara daring menggunakan media pembelajaran digital; (2) penerapan bahan ajar atau materi seni budaya secara digital; (3) tujuan pembelajaran tercapai sesuai rencana pelaksanaan pembelajaran daring.Oleh karena itu dari hasil temuan tersebut maka proses digitalisasi yang diterapkan di SMA N 9 Manado dapat menjadi strategi pembelajaran dimasa pandemi. Penelitian ini direkomendasikan untuk menjadi bahan acuan pendidikan yang inovatif dalam menghadapi tantangan zaman. Sebagai pembelajaran yang efektif pada masa pandemi.
\end{abstract}

\section{Kata kunci : Digitalisasi, Seni Budaya}

\begin{abstract}
This study aims to explain the process of digitizing learning at SMA N 9 Manado starting from the preparation of digital materials, the application of the Microsoft 365 application, and the process of implementing digital cultural arts learning. This research is a qualitative research using case studies. Data were collected through observation, interviews and documentation results. This research was conducted using qualitative methods and utilizing descriptive data related to data collection to provide an overview or confirmation of a concept or phenomenon related to the digitization of cultural arts learning at SMA N 9 Binsus Manado. the process of teaching and learning activities is carried out online using digital learning media; (2) the application of digital teaching materials or cultural arts materials; (3) learning objectives are achieved according to the online learning implementation plan. Therefore, from the findings, the digitization process implemented at SMA N 9 Manado can be a learning strategy during the pandemic. This research is recommended to be a reference for innovative education in facing the challenges of the times. As an effective learning during a pandemic.
\end{abstract}

\section{Keywords: Digitalization, Arts and Cultures}




\section{Pendahuluan}

Pendidikan sangat penting dalam proses pertumbuhan sehingga mendapatkan pengetahuan, keterampilan dan keahlian maupun sikap dan pembentukkan karakter. Pendidikan tidak memiliki batasan usia dari generasi ke generasi waktu ke waktu dan terus berinovasi sesuai dengan berkembangnya teknologi.

Di dalam UU No. 20 Tahun 2003 tentang Sistem Pendidikan Nasional pada pasal 13 ayat (1) disebutkan bahwa jalur pendidikan terdiri atas pendidikan formal, non formal dan informal yang dapat saling melengkapi dan memperkaya. ${ }^{1}$ Pendidikan formal (sekolah) adalah pendidikan yang diperoleh seseorang di sekolah secara teratur, sistemastis, bertingkat, dan dengan mengikuti syarat-syarat yang jelas dan ketat (mulai dari taman kanak-kanak sampai perguruan tinggi). ${ }^{2}$ Pendidikan sekolah memiliki tugas utama yakni mengajar para siswa atau murid untuk belajar. Dalam proses belajar tentunya membutuhkan peranan guru. menurut Hasbullah peranan guru adalah sebagai motivator; stimulator, dan penunjuk jalan

\footnotetext{
${ }^{1}$ Hasbullah, Dasar-Dasar IImu

Pendidikan : Fungsi dan Peran Lembaga

Pendidikan (Jakarta: Rajawali Pers, 2015), hal. 49

${ }^{2}$ Ibid hal. 46

${ }^{3}$ Hasbullah, Dasar-Dasar IImu Pendidikan : Strategi Pendidikan Seumur Hidup (Jakarta: Rajawali Pers, 2015), hal. 83
}

anak didik dalam hal belajar (learning centre) bagi masyarakat sekitarnya. ${ }^{3}$ Oleh karena itu guru yang merupakan komponen penting di bidang kependidikan tentunya harus aktif dalam menjalankan tugasnya sebagai guru yang profesional, sesuai dengan kebutuhan masyarakat yang terus mengalami perkembangan. Artinya guru memiliki tanggung jawab besar dalam proses pembelajaran untuk memberikan ilmu pengetahuan bahkan dalam memberikan pembinaan mental spiritual dari anak didik. Dalam hal ini guru tidak hanya sebagai pengajar saja tetapi juga sebagai pendidik dan sekaligus pembimbing untuk mengarahkan siswa dalam belajar.

Pandemi virus corona membuat dunia menjadi panik karena penyebarannya yang sangat cepat. virus ini bisa menginfeksi semua orang tanpa kenal usia. Virus corona atau biasa juga disebut dengan covid-19 dapat menyebabkan infeksi saluran pernapasan baik ringan maupun berat. Kemunculan virus korona awalnya terdeteksi di negara China kemudian menyebar keseluruh negara lainnya termasuk di Indonesia. ${ }^{4}$

${ }^{4}$ http://indonesia.go.id/narasi/indonesia-dalamangka/ekonomi/kasus-covid-19pertamamasyarakat-jangan-panik (diakses 28 Maret 2021, pukul 19.30 WITA) 
Akibat meluasnya penyebaran virus corona di Indonesia, pemerintah melakukan banyak cara untuk mencegah penyebaran virus corona. Antara lain melalui surat edaran Kementrian Pendidikan dan Kebudayaan Direktorat Pendidikan Tinggi No. 1 tahun 2020 tentang pencegahan penyebaran Corona Virus Disease (Covid-19) di sekolahsekolah. Dengan demikian melalui surat edaran ini dari pihak Kemendikbud memerintahkan agar kegiatan belajar mengajar di sekolah dilakukan dengan sistem pembelajaran secara daring yang memungkinkan siswa bisa belajar dari rumah.

Proses pembelajaran secara daring membutuhkan penguasaan teknologi. Kemajuan teknologi saat ini membuat semua kalangan termasuk lembaga pendidikan menerapkan pembelajaran yang serba digital. Digitalisasi adalah salah satu bentuk inovasi yang berguna dalam proses pembelajaran di tengah pandemi virus corona. Materi serta bahan ajar yang akan diberikan bisa di virtualisasikan lewat aplikasi-aplikasi yang dapat memberikan rangsangan kegiatan belajar agar tidak bosan dan memberikan motivasi untuk mendalami proses pembelajaran.

5

https://id.wikipedia.org/wiki/SMA_Negeri_9_Binsus_Mana do (diakses 29 Maret)
SMAN 9 Manado merupakan sekolah yang terakreditasi baik dan salah satu sekolah unggulan di Sulawesi Utara. Sekolah ini memiliki siswa yang berprestasi pada kegiatan intrakurikuler maupun ekstrakurikuler. SMAN 9 Manado memiliki kelas Binsus (Binaan Khusus), siswa dikelas Binsus merupakan siswa unggulan sekolah yang memiliki kemampuan tinggi dan dibimbing secara khusus dalam meningkatkan prestasi sekolah. ${ }^{5}$

Agar siswa di SMAN 9 Binsus Manado bisa berhasil dalam proses belajar mengajar di tengah pandemi, dari observasi pihak sekolah menerapkan sistem pembelajaran secara digital dengan menggunakan aplikasi microsoft 365 . Sistem pembelajaran digital yang diterapkan sangat membantu dalam mencapai tujuan pembelajaran. Hal ini dapat dilihat dari hasil nilai serta respon tugas siswa pada mata pelajaran seni budaya. Dari fenomena ini dapat di katakan bahwa sistem pembelajaran digital yang di terapkan di sekolah SMAN 9 Binsus Manado cukup berhasil dibandingakan dengan sekolah lain yang belum maksimal menerapkan sistem pembelajaran daring hal ini dapat dilihat dari beberapa pihak 
sekolah yang menyatakan bahwa banyak kendala yang terjadi pada proses pembelajaran jarak jauh namun akan

\section{Metode}

Penelitian ini menggunakan metode penelitian deskriptif kualitatif. Peneltian kualitatif adalah suatu pendekatan penelitian yang mengungkapkan situasi sosial tertentu dengan mendeskripsikan kenyataan secara benar, menggunakan kata-kata berdasarkan teknik pengumpulan data dengan analisis data yang relevan yang diperoleh dari situasi yang alamia. ${ }^{7}$ Jenis penelitian ini menggunakan penelitian deskriptif, yaitu suatu metode penelitian untuk membuat gambaran mengenai situasi atau kejadian. Sehingga mampu mendapatkan berbagai informasi yang dibutuhkan. Metode kualitatif sebagai prosedur penelitian yang menghasilkan data deskriptif berupa kata-kata atau lisan dari orang-orang atau perilaku yang dapat diamati. ${ }^{8}$

\section{Hasil dan Pembahasan}

Sekolah SMA N 9 Manado merupakan sekolah yang unggul dan

\footnotetext{
${ }^{6}$ https://manadoxpress.com/berita-17862sekolahsekolah-masih-menghadapi-kendalabelajar-daring-.html (diakses $10 \mathrm{Juni}$ )
}

berusaha menemukan solusi sehingga proses belajar mengajar tetap berjalan dengan baik. ${ }^{6}$

terakreditasi baik di Sulawesi Utara. Hal ini dapat dilihat dari berbagai prestasi dari siswa-siswi SMA N 9 Manado baik kegiatan intrakurikuler maupun ekstrakurikuler. Pandemi virus Covid-19 membuat seluruh kegiatan aktivitas belajar mengajar di sekolah menjadi online atau daring sehingga terdapat perbedaan pada proses kegiatan belajar mengajar dimana sebelumnya dilakukan secara langsung di sekolah dan pada masa pandemi proses kegiatan belajar mengajar dilakukan secara jarak jauh. Dari hasil observasi sekolah SMA N 9 Manado menerapkan sistem pemebalajaran digital sebagai strategi agar tujuan pembelajaran tecapai pada masa pandemi. Hal ini berkaitan dengan teori strategi menurut Shirley yang menyatakan bahwa:

"strategi dirumuskan sebagai keputusankeputusan bertindak yang diarahkan dan

\footnotetext{
7 Sugiyono, Metode Penelitian Kualitatif. Bandung: Alfabeta 2021

${ }^{8}$ Lexy J. Moelyong, Metodologi Penelitian Kualitatif (Bandung: Remaja Rosdakarya, 2006). Hal.4
} 
keseluruhannya diperlukan untuk mencapai tujuan. $^{9}$

\section{a. Digitalisasi pembelajaran}

Berikut merupakan proses digitalisasi pembelajaran di SMA $N 9$ Manado:

1) Proses pembuatan materi digital Pada proses pembuatan materi dalam bentuk digital guru menggunakan perangkat seperti komputer atau laptop serta beberapa aplikasi pendukung dimana perangkat ini akan di pakai sebagai media pembelajaran digital. Bahan ajar berupa bukubuku pelajaran seni budaya yang berisikan materi pembelajaran disalin ke aplikasi presentasi seperti power point begitu juga dengan tugas-tugas harian sampai tugas untuk ujian akhir, di salin ke dalam bentuk dokumen digital seperti microsoft word, Pdf, atau

2) Media pembelajaran digital Sekolah SMA N 9 Manado menggunakan aplikasi microsoft teams sebagai media pembelajaran virtual di masa pandemi covid-19. Aplikasi ini dapat digunakan baik guru maupun siswa untuk foto yang dikirim ke siswa menggunakan aplikasi microsoft teams. Berdasarkan teori digitaliasi yang ada mengatakan bahwa:

Proses digitalisasi adalah kegiatan mengubah dokumen tercetak menjadi dokumen digital. ${ }^{10}$

Dengan demikian guru akan terbantu pada proses belajar mengajar dalam mencapai tujuan pembelajaran berdasarkan rencana pembelajaran digital dimana waktu untuk mengajar guru selama $1 \times 30$ menit. Pada proses digitalisasi pembelajaran seni budaya di SMA N 9 Manado belum ada guru yang membuat video pembelajaran karena keterbatasan pengetahuan teknologi, maka dari itu guru hanya memanfaatkan video pembelajaran dari internet.

melakukan proses kegiatan belajar mengajar. Microsoft teams memiliki beberapa fitur yang dapat dimanfaatkan guru dalam proses mengajar seperti adanya fitur presentasi pada saat meeting dimana guru bisa menampilkan

\footnotetext{
${ }^{9}$ Anissatul Mufarokah, Strategi Belajar Mengajar (Yogyakarta: Teras, 2009), hal. 36
} 
materi-materi yang sudah disiapkan dalam berbagai jenis format file seperti; powerpoint, video, dan document jenis lainnya, kemudian adanya fitur obrolan dalam bentuk grub dan pesan pribadi untuk dijadikan bahan diskusi atau tanya jawab mengenai materi pembelajaran seni budaya. Pada microsoft teams guru dapat memberikan tugas sekaligus bisa mengatur waktu batas pengumpulan tugas kemudian dikirim dan tugas tersebut langsung masuk ke kotak pemberitahuan pesan pada akun microsft teams siswa. Siswa dapat mengerjakan tugas tersebut kemudian dikirim dalam beberapa format file seperti foto, video, dokumen sesuai dengan permintaan tugas dari guru. Selanjutnya guru dapat melihat tugas yang telah dikirim siswa di kotak penilaian dan guru bisa membuka file tersebut serta bisa memeberikan penilaian di layanan kotak penilaian. Setelah semua siswa sudah mengumpulkan tugastugas tersebut guru bisa mencetak nilai ke microsoft excel dan di bagikan langsung kepada siswa. Berdasarkan teori yang ada berkaitan dengan media pembelajaran digital dikatakan bahwa:

Strategi pembelajaran digital merupakan sistem belajar yang menggunakan alat bantu pendidikan seperti internet dan teknologi berbasis jaringan serta aplikasi yang mendukung suatu pembelajaran sehingga tujuan pembelajaran tercapai. ${ }^{11}$

Aplikasi ini sudah sepenuhnya berbasis digital. Hal ini merupakan suatu perencanaan dari pihak sekolah agar para peserta didik dapat belajar dengan hasil yang maksimal. Dengan menggunakan sistem pembelajaran ini siswa dan guru bisa melakukan kegitan belajar mengajar dari rumah. Dimana masa pandemi ini mengharuskan siswa dan guru tidak bisa beraktivitas di dalam kelas, berkaitan dengan teori berikut:

Sistem pembelajaran digital merupakan suatu sistem yang dapat memfasilitasi pembelajar belajar lebih luas, lebih banyak, dan bervariasi. Melalui fasilitas yang disediakan oleh sistem tersebut, pembelajar dapat belajar kapan dan dimana saja

${ }^{11}$ Ibid, h.16 
tanpa terbatas oleh jarak, ruang dan waktu. ${ }^{12}$

Guru juga bisa langsung memberikan tugas serta informasi lainnya di luar jadwal mengajar tanpa mengadakan pertemuan. Berdasarkan teori berikut:

\begin{tabular}{lr}
\multicolumn{1}{c}{ Dengan } & \multicolumn{2}{c}{ menggunakan } \\
pembelajaran digital, dapat & daja \\
berkomunikasi & kemana \\
secara cepat & dengan \\
menggunakan & aplikasi \\
Chatting. $^{13}$ &
\end{tabular}

Microsft teams memudahkan guru untuk mengevaluasi tugas yang di kirim siswa dimana semua data tugas yang dikirim dalam bentuk dokumen, foto, video dan format lainnya tersimpan di microsoft teams yang dapat diakses kapan saja. Di dalam pembelajaran digital itu, pembelajar dapat mengakses alat atau media yang akan membuat mereka dapat mengulang materi pembelajaran dan berinteraksi dengan pembelajar lainnya meskipun tempatnya berbeda-beda dan berjauhan.

3) Penerapan microsoft 365 Untuk menerapkan aplikasi microsft 365 sebelumnya diadakan rapat perencanaan bersama operator IT sekolah SMA N 9 Manado untuk membahas aplikasi yang bisa mendukung keseluruhan rangkaian kegiatan di sekolah baik proses belajar mengajar sampai pada kegiatan evaluasi. Kemudian dari pihak operator sekolah menemukan solusi dengan menerapkan aplikasi microsft 365 sebagai media untuk menjadikan sistem pembelajaran digital di sekolah SMA N 9 Manado. Langkah awal untuk menggunakan microsoft 365, operator sekolah mendaftarkan akun microsoft untuk SMA N 9 Manado kemudian dilanjutkan dengan mengikuti berbagai persyaratan dan training selam beberapa waktu untuk mendapatkan akun resmi microsoft 365 agar seluruh fitur bisa di akses termasuk kelas digital microsoft teams. Setalah mendapatkan akun resmi microsoft 365 dibuatlah akun untuk fitur kelas digital microsoft teams.

Pada proses pembuatan akun microsoft teams membutuhkan data-data dari semua guru dan siswa berdasarkan kelas dan mata pelajaran yang ada. Ada dua jenis akun microsoft teams yang dipakai yakni akun untuk guru dan akun 
untuk siswa dimana ada fitur yang hanya bisa diakses oleh guru, fitur tersebut adalah pembuatan tugas dan penilaian. Sistem kerja aplikasi ini berpusat pada satu server atau admin yang menyimpan semua data aktivitas proses belajar mengajar sehingga memudahkan kepala sekolah dan wakil kepala sekolah bidang kurikulum untuk mengevaluasi hasil pembelajaran baik siswa maupun guru. Berdasarkan teori yang ada yang berkaitan dengan sistem pembelajaran digital mengatakan bahwa:

Sistem pembelajaran digital dengan memanfaatkan media lewat aplikasi yang mendukung aktivitas pendidikan juga memiliki kemampuan untuk memantau kegiatan guru, dan siswa pada evaluasi mengajar sehingga para guru semakin menyadari bagaimana kemampuan para siswa di dalam belajarnya dan sebaliknya keahlian guru untuk mrngajar. ${ }^{14}$

Microsoft 365 dapat memantau seluruh aktivitas mengajar para guru melalui kelas digital microsoft teams mulai dari kehadiran,waktu mengajar, proses mengajar serta materi dan tugas yang diberikan.

b. Metode pembelajaran seni budaya secara digital dalam mencapai tujuan pembelajaran

1) Penggunaan teknologi digital Guru seni budaya memanfaatkan teknologi digital yang ada untuk dijadikan sumber informasi belajar kepada siswa misalkan memberikan video pembelajaran sesuai materi yang akan disampaikan pada pertemuan nanti lewat fitur obrolan di aplikasi pembelajaran microsoft teams. Berdasarkan teori yang ada dikatakan bahwa:

Pembelajaran digital memiliki kemampuan untuk mengirimkan data, baik berupa teks, pesan, video maupun audio. ${ }^{15}$

Berdasarkan teori di atas guruguru bisa memanfaatkan teknologi digital pada proses mengajar dengan memberikan materi-materi diluar pertemuan. Dengan begitu guru dapat menghemat waktu pada pertemuan virtual diman waktu pertemuan hanya $1 \times 30$ menit. Maka siswa dapat belajar secara maksimal dengan belajar mandiri di rumah. Guru juga mengarahkan agar siswa bisa memfasilitasi 
aplikasi microsoft teams sebagai sarana untuk mendiskusikan seluruh bahan pelajaran yang bisa di jelaskan langsung oleh guru di orbrolan maupun akan di jelaskan pada pertemuan virtual nantinya. Berdasarkan teori yang ada mengatakan bahwa:

Strategi student expedition, dimana guru memberikan materi pembelajaran yang akan dipelajari terlebih dahulu sehingga siswa dapat belajar lewat media online. ${ }^{16}$

2) Materi dan tugas digital

Proses mengajar yang dilakukan guru lewat media pembelajaran digital yakni microsoft teams memberikan layanan yang dapat dimanfaatkan guru dalam memberikan materi pembelajaran untuk siswa. Layanan tersebut berupa presentasi secara digital menggunakan bahan ajar lewat materi-materi seni budaya yang telah disiapkan sebelumnya dalam bentuk dokumen digital seperti powerpoint, microsoft word, Pdf, foto, video dan audio. Guru memulai pembelajaran dengan mengundang siswa masuk ke kelas yang sudah di jadwalkan guru dan siswa bisa masuk ke dalam kelas tersebut menggunakan aplikasi yang sama (microsoft teams). Selanjutnya guru dapat mempresentasi kepada siswa bahan ajar materi pembelajaran seni budaya secara digital. Berdasarkan teori yang ada mengatakan bahwa :

Dengan bentuk presentasi yang memanfaatkan visualisasi yang bagus disertai audio akan membantu siswa untuk mudah menyerap materi pembelajaran dan memberikan rangsangan untuk fokus pada pelajaran. ${ }^{17}$

Dengan memberikan metode seperti teori di atas siswa bisa lebih fokus dan tidak bosan pada proses pembelajaran sehingga siswa bisa dengan mudah memahami dengan jelas materi yang diberikan.

Bentuk evaluasi pembelajaran siswa dilakukan secara digital dimana siswa merespon seluruh pembelajaran yang diberikan guru lewat tugas akhir seni budaya dalam bentuk ujian secara teoritik dan praktik dan dibuat dalam format digital. Tugas praktik dibuat dalam bentuk video dari materi pembelajaran seni budaya kelas XII SMA N 9 Manado yaitu musik 
kontemporer yang dibuat secara berbentuk

kelompok.

Pengelompokkan dibuat melalui grub pada aplikasi microsoft teams dan guru mengarahkan siswa untuk saling berkordinasi perkolempok juga mengontrol proses pembuatan video melalui pertemuan virtual. Siswa perkelompok saling bekerja dalam bentuk diskusi pada proses penyelesaian tugas praktik dalam bentuk video. ${ }^{18}$

3) Esensi pendidikan musik di sekolah

Pada proses pelaksanaan aktivitas musikal, guru memberikan tugas praktek musik kontemporer dan dibuat dalam bentuk digital seperti video yang akan ditampilkan pada pertemuan kelas digital. Di sini siswa dilatih untuk menciptakan kreativitas dan ide bermusik ke dalam bentuk digital. Tugas praktek yang diberikan guru membuat siswa lebih berkreasi dalam memanfaatkan teknologi yang ada. Berkaitan dengan teori yang dikemukakan Pamadhi bahwa :

$$
\begin{aligned}
& \text { Substansi kreasi pada } \\
& \text { pendidikan seni di sekolah } \\
& \text { diartikan sebagai penciptaan } \\
& \text { menuntut ide, dengan tujuan }
\end{aligned}
$$

$$
\begin{aligned}
& \begin{array}{l}
\text { menumbuhkan ide-ide baru } \\
\text { yang } \\
\text { dipertanggungjawabkan. }
\end{array}
\end{aligned}
$$

Dari hasil evaluasi guru seni budaya dinyatakan bahwa siswa bisa menyelesaikan tugas praktek digital membuat video musik kontemporer sehingga tujuan pembelajaran seni budaya tercapai.

\section{Kesimpulan}

Berdasarkan hasil penelitian yang yang membahas mengenai digitalisasi pembelajaran seni budaya di kelas XII SMA N 9 Binsus Manado, dapat disimpulkan bahwa :

1. Pada proses digitalisasi, guru seni budaya menyiapkan materi-materi dari buku pembelajaran kemudian dibuat ke dalam format power point untuk dipresentasikan, ada juga menyiapkan video pembelajaran yang di ambil dari internet memang belum ada guru yang menyediakan video pembelajaran sendiri karena kemampuan penguasaan teknologi yang terbatas.

2. Pembelajaran seni budaya di SMA N 9 Binsus Manado menggunakan aplikasi microsoft 365 sebagai media pembelajaran di masa pandemi Covid-19. Pada

${ }^{18}$ ibid, h. 18-19 
penerapan pemakaian aplikasi ini dilakukan pelatihan untuk guruguru selama 3 hari kemudian langsung di praktekkan dengan siswa. Fungsi dari microsoft 365 sangat membantu sekolah dalam menjalankan aktifitas kegiatan belajar mengajar sehingga sistem pembelajaran ini akan tetap digunakkan pada masa pandemi sesuai pernyataan kepala sekolah. Dampak yang di rasakan guru dan siswa terdapat pada waktu mengajar yang di berikan yakni 30 menit, guru bisa kurang maksimal dalam menjelaskan matari karena waktu yang tidak cukup begitu juga siswa ada yang kurang puas karena waktu yang tidak maksimal ditambah dengan kendala seperti gangguan jaringan sehingga siswa agak sulit untuk memahami semua penjelasan guru. Dan untuk mengatasi siswa yang perlu bantuan perangkat belajar sekolah menyiapkan perangkat hanphone kepada siswa yang memerlukan.

3. Penerapan metode pada sistem pembelajaran digital seni budaya, guru-guru memanfaatkan media pembelajaran visual berupa video pembelajaran kemudian di bagikan kepada siswa sehingga siswa dapat mempelajari lagi materi tersebut kapan dan dimana saja. Hal ini dapat membantu agar siswa yang belum paham disaat guru menjelaskan materi akibat faktor waktu yang tidak cukup maupun kendala seperti gangguan pada jaringan internet bisa teratasi. Dan jika ada siswa yang belum bisa mengerti secara jelas materi yang diberikan guru bisa di bahas melalui fitur obrolan yang ada di aplikasi microsoft teams.

4. Tugas praktek seni budaya dibuat dalam bentuk digital dimana guru mengarahkan siswa dalam proses pembuatan video musik kontemporer. Berdasarkan hasil analisis proses pelaksanaan aktivitas musikal yang dilakukan secara digital tidak mengubah esensi pendidikan musik di kelas XII SMA N 9 Binsus Manado.

\section{Kepustakaan}

Administrator, Kasus Covid-19 Pertama Masyarakat Jangan Panik, http://indonesia.go.id/narasi/ind onesia-dalamangka/ekonomi/kasus-covid-19pertama-masyarakat-janganpanik (diakses 29 Maret 2021, pukul 18.30 WITA)

Dabbagh, N. And Ritland. B. B. Online Learning, concepts, Strategies And Application. (Ohio: Pearson. 2005)

Darmansyah. Strategi Pembelajaran Menyenangkan dengan Humor (Jakarta:Bumi Aksara, 2010 
Depdikbud, Kamus Besar Bahasa Indonesia, (Jakarta : Balai Pustaka, 1990)

Diraktorat Tenaga Kependidikan, Strategi Pembelajaran dan Pemilihannya (Jakarta : Dipdiknas, 2008)

Hasbullah, Dasar-Dasar IImu Pendidikan : Fungsi dan Peran Lembaga Pendidikan (Jakarta: Rajawali Pers, 2015)

Hamalik Oemar, Proses Belajar Mengajar, (Jakarta : Bumi Aksara, 2001)

Indra Wicaksono, Penggunaan Musik Sebagai Media Pembelajaran Seni Di Taman Kanak-Kanak Hj. (diakses pada 20 Maret 2021 pukul 21.40 WITA)

Kaiful Uman, Penerapan Media Digital Dalam Pembelajaran Apresiasi Batik Kelas X SMA Negeri 1 Blega. (diakses pada 20 Maret 2021 pukul 20.47 WITA)

Moelyong J. Lexy, Metodologi Penelitian Kualitatif (Bandung: Remaja Rosdakarya, 2006). Hal.4

Mustofa, Digitalisasi Koleksi Karya Sastra Balai Pustaka Sebagai Upaya Pelayanan Di Era Digtal Natives (2018:61) https://ejournal.unair.ac.id/JPERPUS/art icle/download/20686/11483 (diakses 29 Maret 2021 pukul 15.55 WITA)

Mufarokah Anissatul, Strategi Belajar Mengajar (Yogyakarta: Teras, 2009)

Muhaimin M.A, Strategi Belajar Mengajar, (Surabaya : Citra Media. 1996)
Nurfatoni Septian, Kajian Gambar Ekpresi Karya Siswa Tingkat Sekolah Dasar http://repository.upi.edu/4953/5/ S PSR 0900126 Chapter2 (diakses 8 agustus 2021 pukul 8:46)

Munir, Pembelajaran Digital. Bandung: Alfabeta 2017

Rustam Aji, Digitalisasi, Era Tantangan Media (2016:2), https://journal.walisongo. ac.id/index.php/icj/article/downloa d/1245/968 (diakses 28 Maret 2021 pukul 18.45 WITA)

Shady Vidi, Sekolah-Sekolah Masih Menghadapi Kendala Belajar Daring.

https://manadoxpress.com/berita17862-sekolahsekolah-masihmenghadapi-kendalabelajardaring-.html (diakses 10 Juni)

Sugiyono, Metode Penelitian Kualitatif. Bandung: Alfabeta 2021

Suwarno, Pengantar Umum Pendidikan, Aksara Baru, Jakarta, 1985

Syaiful Bahri Djamarah \& Aswan Zain. Strategi Belajar Mengajar. (Jakarta:Rineka Cipta. 2010)

Tim Pustaka Yustisia. Panduan Lengkap KTSP (Kurikulum Tingkat Satuan Pendidikan).(Yogyakarta: Pustaka Yustisia. 2007). Hal 162.

Yanuarita Sutikno Putri, Era Digital? "Pendidikan Seni Musik Berbasis Budaya" (diakses pada 19 Maret 2021 pukul 20.25 WITA) 